\title{
The Pronominal System of the Souotri Dialects: A structural and functional Study
}

\author{
Khaled Awadh Bin Mukhashin * \\ (Hadhramout University, Yemen) \\ Munir Shuib ** \\ (Universiti Sains Malaysia, Malaysia)
}

\begin{abstract}
This study aims at describing structurally and functionally the pronominal system of the three main dialects of Soqotri, an endangered Modern south Arabian language spoken in the Island of Soqotra, Yemen. A part of the data presented in the study has been taken from my PhD thesis written in 2009. New data were collected from the field in 2012 and added to the study. The Study follows a descriptive method, therefore, showing no argumentation. The study reveals the structure and functions of the Soqotri rich pronominal system. It shows that the three Soqotri dialects (Eastern Soqotri Dialect, Central Soqotri Dialect and Western Soqotri Dialect) have personal pronouns, possessive pronouns, demonstrative pronoun, reflexive pronouns, reciprocal pronouns, relative pronouns and interrogative pronouns. It also shows that these pronouns are usually of two types (independent and dependent) inflecting for person, number and gender.
\end{abstract}

Keywords: Soqotri, Modern south Arabian language, pronominal system, pronouns

\section{Introduction}

Soqotri belongs to a language group called Modern South Arabian Languages (MSA). This group includes Soqotri, Mehri, Jibbali, Hobyot, Harsusi and Bathari. MSA language are the remnant of a pre-Arabic linguistic substrate that once expanded from Oman in the east to the high lands of Yemen in the west that included the already dead Old South Arabian Languages OSA: Sabaean, Minaean, Gatabanian and Hadramic. These south Semitic languages extended across the Red Sea to the highlands and costal area of East

* Dr. Khaled Awadh Bin Mukhashin: Assistant Professor, School of Arts, Hadhramout University, Mukalla P.O.Box 50512 Hadhramot, Yemen. Areas of Specialisation: Syntax and morphology, Semitic linguistics, Modern South Arabian languages. Email address: kbinmukhashin@gmail.com; K_binmukhashin@ yahoo.com.

${ }_{* *}$ Dr. Munir Shuib: Assistant Professor, School of Humanities, Universiti Sains Malaysia,11800 Pulau Pinang, Malaysia. Areas of Specialisation: Grammar, English for Specific Purposes, Applied Linguistics. Email address: munir@usm.my. 
Africa creating the Ethiosemitic languages such as Ge'es, Amharic and Tigrina (Leibhaber, 2007).

Soqotri is called sək'ət'əri or sək'ət'ərijəh by its speakers and it is written either as Soqotri or Socotri. It has three main dialects (Eastern Soqotri Dialect, Central Soqotri Dialect and Western Soqotri Dialect). Soqotri is spoken only in the islands of Soqotra archipelago in Yemen and by the Soqotri immigrants in the Arabian Gulf States mainly in Ajman in the United Arab Emirates. Soqotra archipelago consists of Soqotra, the main and largest island, the island of Abd al-Kuri, Samha Island and Darsa Island. Soqotra archipelago is located in the Arabian Sea around 300 kilometers south of the Arabian Peninsula and 240 kilometers from the coasts of Africa. It is between the latitudes 12, 8-12, 42 north of the equator and the longitudes 53, 19-54, 33 east of Greenwich (Zorman, 2006).

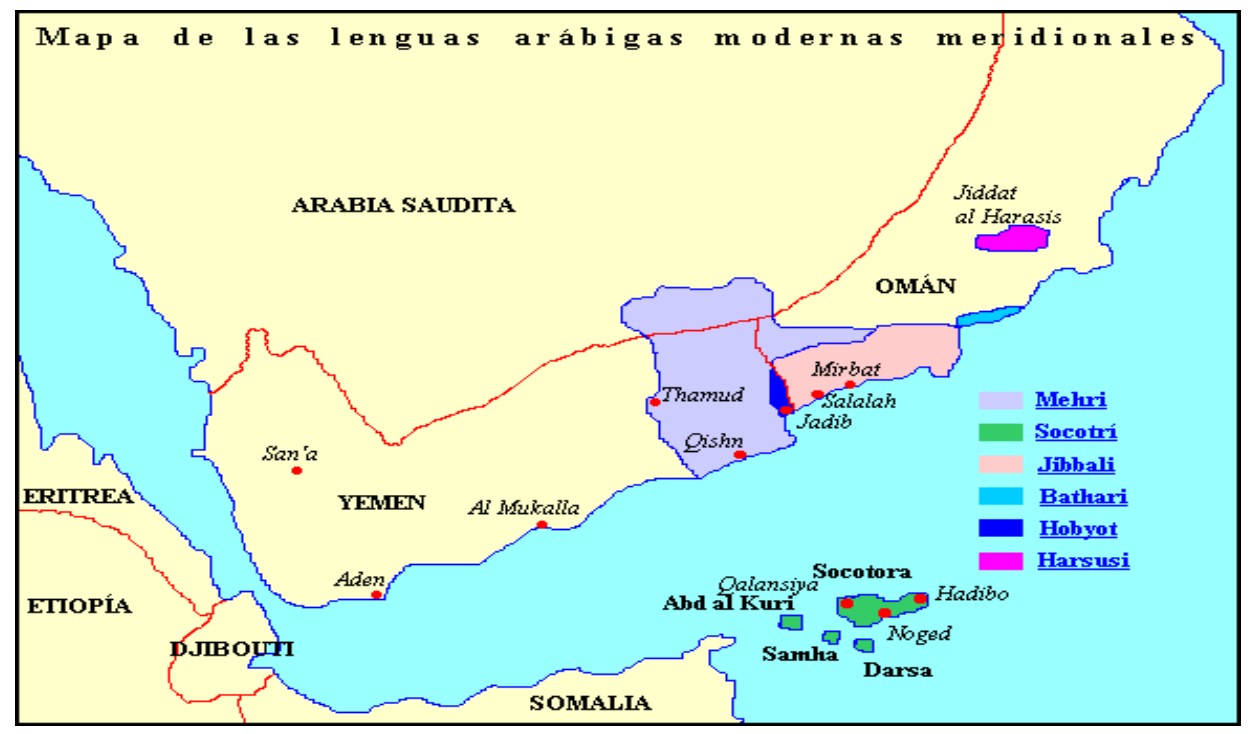

Figure 1. Map of Modern South Arabian Languages (Simeone-Senelle, 1997:381)

\section{Previous Studies on Soqotri Pronouns}

Leslau (1938) provided a brief description for the personal pronoun in Soqotri. The data Leslau analyzed are from Muller's texts. Simeone-Senelle (1997) also described Soqotri personal pronouns briefly. Naumkin (1998) studies the personal pronouns used in the everyday speech of the Soqotrans who live in the eastern part of the island and compares them with the personal pronouns used in the traditional old folktales and stories. He found out that there are differences between the personal pronouns used in every day spontaneous speech and those used in traditional folktales and stories. The former pronouns have short forms while the later have full forms. 
The Pronominal System of the Soqotri Dialects: A structural and functional Study

\section{Significance of the study}

The significance of this study lies in the fact that it is the first study ever that investigates structurally and functionally the rich pronominal system not only in one Soqotri dialect but in all the three main Soqotri dialects providing genuine data documented for the first time.

\section{Soqotri Personal Pronouns:}

Soqotri has two sets of personal pronouns independent or (free personal pronouns) and dependent or (bound personal pronouns). They inflect for person, number and gender. The functions, structures and paradigms of these pronouns will be described in the following sections.

\subsection{Independent Personal Pronouns}

The independent or free personal pronouns are those which occur independently as separate words. They stand on their own as substitute for nouns or noun phrase. They refer to persons or entities. They are sometimes referred to as subject pronouns since they can serve as the subjects of the verbs and they correspond to the set of English subject pronouns. These pronouns show differences in gender (masculine and feminine), number (singular, dual and plural) and person (first, second and third).There is no neutral pronoun in the Soqotri because there is no neutral gender in this language. Everything is referred to either as masculine or as feminine. The following tables contain the independent personal pronouns in the three Soqotri dialects.

Table 1. Independent Subject Personal Pronouns in the Eastern Soqotri Dialect

\begin{tabular}{|c|c|c|c|c|}
\hline Person & Gender & Singular & Dual & Plural \\
\hline $1^{\mathrm{st}}$ & $\mathrm{M} / \mathrm{F}$ & hoh 'I' & kih 'we two' & ћعn 'we' \\
\hline $2^{\text {nd }}$ & $\begin{array}{l}M \\
F\end{array}$ & $\begin{array}{l}\text { hæt, Pəh 'you' } \\
\text { hit,?Ih 'you' }\end{array}$ & $\begin{array}{l}\text { tih 'you two' } \\
\text { tih 'you two' }\end{array}$ & $\begin{array}{l}\text { tæn 'you' } \\
\text { tæn 'you' }\end{array}$ \\
\hline $3^{\text {rd }}$ & $\begin{array}{l}M \\
F\end{array}$ & $\begin{array}{l}\text { jheh 'he' } \\
\text { seh 'she' }\end{array}$ & $\begin{array}{l}\text { jeheh 'they two' } \\
\text { jehch 'they two' }\end{array}$ & $\begin{array}{l}\text { jhæn 'they' } \\
\text { sæn 'they' }\end{array}$ \\
\hline
\end{tabular}

Table 2. Independent Subject Personal Pronoun in the Soqotri Central Dialect

\begin{tabular}{|c|c|c|c|c|}
\hline Person & Gender & Singular & Dual & Plural \\
\hline $\mathrm{I}^{\mathrm{st}}$ & $\mathrm{M} / \mathrm{F}$ & hoh 'I' & kih 'we two' & ћعn 'we' \\
\hline $2^{\text {nd }}$ & $\begin{array}{l}M \\
F\end{array}$ & $\begin{array}{l}\text { hət, ?əh 'you' } \\
\text { hit, ?Ih 'you' }\end{array}$ & $\begin{array}{l}\text { tih 'you two' } \\
\text { tih 'you two' }\end{array}$ & $\begin{array}{l}\text { tæn 'you' } \\
\text { tæn 'you' }\end{array}$ \\
\hline $3^{\text {rd }}$ & $\begin{array}{l}M \\
F\end{array}$ & $\begin{array}{l}\text { jheh 'he' } \\
\text { sch 'she' }\end{array}$ & $\begin{array}{l}\text { jeheh 'they two' } \\
\text { jehch 'they two' }\end{array}$ & $\begin{array}{l}\text { jhæn 'they' } \\
\text { sæn 'they' }\end{array}$ \\
\hline
\end{tabular}


Khaled Awadh Bin Mukhashin \& Munir Shuib

Table 3. Independent Subject Personal Pronouns in the Western Soqotri Dialect

\begin{tabular}{|c|c|c|c|c|}
\hline Person & Gender & Singular & Dual & Plural \\
\hline $1^{\mathrm{st}}$ & $\mathrm{M} / \mathrm{F}$ & Pعh, hoh 'I' & kih 'we two' & ћعn 'we' \\
\hline $2^{\text {nd }}$ & $\begin{array}{l}\mathrm{M} \\
\mathrm{F}\end{array}$ & $\begin{array}{l}\text { Pət 'you' } \\
\text { Pit, hit 'you' }\end{array}$ & $\begin{array}{l}\text { tih 'you two' } \\
\text { tih 'you two', }\end{array}$ & $\begin{array}{l}\text { tən, tæn 'you' } \\
\text { tعn, tæn 'you' }\end{array}$ \\
\hline $3^{\text {rd }}$ & $\begin{array}{l}M \\
F\end{array}$ & $\begin{array}{l}\text { jeh, jheh 'he' } \\
\text { sch 'she' }\end{array}$ & $\begin{array}{l}\text { ji:h, jeheh 'they two' } \\
\text { ji:h 'they two' }\end{array}$ & $\begin{array}{l}\text { jən, jhæn 'they' } \\
\text { sen, sæn 'they' }\end{array}$ \\
\hline
\end{tabular}

As shown in the above tables, number and gender are highly prominent in the independent pronominal system of the Soqotri dialects. However, there is hardly any variation in the forms of the independent subject personal pronouns among the three Soqotri dialects.

The independent personal pronoun in the Soqotri dialects performs many functions. It is used both as an essential part of the clause and as a nonessential part. Since the verb in Soqotri incorporates the subject into its inflections, the independent personal pronoun becomes unnecessary to mark the subject of the verb phrase. However, the personal pronoun can be used along with the verb to fortify or emphasize the subject. Dixon (2007) confirms the existence of this nonessential role of the personal pronouns in many languages. In the following examples, the independent personal pronoun could be dropped and the sentences would still be grammatically correct but the emphasis on the subject will be reduced.

$$
\begin{aligned}
& \text { (1) }(j \varepsilon h) \text { jo- } \int \varepsilon m t \varepsilon l \text { wi : } \\
& \text { He 3SG.M.IMP-speak a lot } \\
& \text { 'He speaks a lot.' } \\
& \text { (2) (sch) s'a:m- sh } \\
& \text { she die-3SG.F.PER }
\end{aligned}
$$

Sometimes this nonessential pronoun is followed by the relative pronoun to add more emphasis on the doer of the action as in this example:

$$
\begin{array}{cccc}
\text { (3) hph d3 } \quad \text { IIn-ək } & \text { Iзh } \\
\text { I } \quad \text { who see-1SG.PAST } & \text { him } \\
\text { 'It is me who saw him.' } &
\end{array}
$$

Nominal clauses in Soqotri have no verbs. They show the subject only through the use of these pronouns. When used in the nominal clause (verbless clause), the pronoun becomes an obligatory and essential part of it.

$$
\begin{array}{rll}
\text { (4) Pət } & \text { deho } & \text { k'a:k'ə } \\
\text { you } & \text { my } & \text { brother }
\end{array}
$$


The Pronominal System of the Soqotri Dialects: A structural and functional Study

'You are my brother.'

The data collected included some uncommon examples in which the independent personal pronoun function as a predicate in the nominal clauses.

(5) Pat jeh
you he
'You are him,

The independent personal pronoun in the Soqotri dialects may function as a copula verb clarifying the relationship between the subject and predicate in nominal clauses.
(6) Səli jeh deho s'a: heb
Ali he my friend

'Ali is my friend.'

In the Soqotri dialects, the independent subject pronouns are sometimes followed by suffixes such as -nə९əh or -hen to magnify and emphasize the subject. Pronouns in the Eastern Soqotri dialect take the suffix $-\mathrm{h} \varepsilon n$, while pronouns in the Western Soqotri dialect take the suffix -nə९əh. In the Middle Soqotri dialect both suffixes are used with pronouns due to the influence of both Eastern and Western dialects on this dialect as it is geographically located between them. These pronouns with their suffixes are also found in the old poems and folk tales.
(7) hp-nə९əh $\quad d \varepsilon$
t'a:hər-k
I who
go-1SG.PAST
'It is me who went.'
(8) $\hbar \varepsilon n-h \varepsilon n \quad n-\int \varepsilon m t \varepsilon l \quad$ sgpt'ri swo
We IPL.PRE-speak Soqotri well
'We speak Soqotri well.'
(9) s\&:-nə९əh t-rojez
She 3SG.F.PRE- dance
'She is dancing.'

Table 4. Independent Subject Personal Pronouns with Suffixes in Eastern Soqotri

\begin{tabular}{|c|c|c|c|c|}
\hline Person & Gender & Singular & Dual & Plural \\
\hline $1^{\text {st }}$ & $\mathrm{M} / \mathrm{F}$ & hohen 'I' & kihen 'we two' & ћعnhen 'we' \\
\hline $2^{\text {nd }}$ & $\begin{array}{l}\mathrm{M} \\
\mathrm{F}\end{array}$ & $\begin{array}{l}\text { Pəhen 'you' } \\
\text { Prhen 'you' }\end{array}$ & $\begin{array}{l}\text { tihen'you two' } \\
\text { tIhen 'you two' }\end{array}$ & $\begin{array}{l}\text { tonhen 'you' } \\
\text { tonhen 'you' }\end{array}$ \\
\hline $3^{\text {rd }}$ & $\begin{array}{l}M \\
F\end{array}$ & $\begin{array}{l}\text { jhehen 'he' } \\
\text { se:hen 'she' }\end{array}$ & $\begin{array}{l}\text { jehehen 'they two' } \\
\text { jehehen 'they two' }\end{array}$ & $\begin{array}{l}\text { jhænhen 'they' } \\
\text { sænhen 'they' }\end{array}$ \\
\hline
\end{tabular}




\section{Khaled Awadh Bin Mukhashin \& Munir Shuib}

Table 5. Independent Subject Personal Pronouns with Suffixes in the Central Soqotri Dialect

\begin{tabular}{|c|c|c|c|c|}
\hline Person & Gender & Singular & Dual & Plural \\
\hline $1^{\text {st }}$ & $\mathrm{M} / \mathrm{F}$ & hæniəh, hæhєn 'I' & kihen, kıniəh 'we two' & h⿻nhpn, ћعnnæSəh 'we' \\
\hline $2^{\text {nd }}$ & $\begin{array}{l}\mathrm{M} \\
\mathrm{F}\end{array}$ & $\begin{array}{l}\text { hətn९əh, Pəhєn 'you' } \\
\text { hitnæYəh, PIhєn 'you' }\end{array}$ & $\begin{array}{l}\text { tinəSəh, tihen 'you two' } \\
\text { tihen, tinəSəh 'you two' }\end{array}$ & $\begin{array}{l}\text { tзnnæイəh, tənhen 'you' } \\
\text { tзnnæYəh, tənhen 'you' }\end{array}$ \\
\hline $3^{\text {rd }}$ & $\begin{array}{l}M \\
F\end{array}$ & 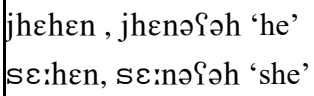 & $\begin{array}{l}\text { jehehen, jehınəSəh 'they two' } \\
\text { jehehen, jehınəSəh 'they two' }\end{array}$ & $\begin{array}{l}\text { jhænhen, jhennəIəh 'they' } \\
\text { sænhen, sennəIəh 'they' }\end{array}$ \\
\hline
\end{tabular}

Table 6. Independent Subject Personal Pronouns with Suffixes in the Western Soqotri Dialect

\begin{tabular}{|c|c|c|c|c|}
\hline Person & Gender & Singular & Dual & Plural \\
\hline $1^{\mathrm{st}}$ & $\mathrm{M} / \mathrm{F}$ & honəSəh 'I' & kinəSəh 'we two' & ћદnnə९əh 'we' \\
\hline \multirow[t]{2}{*}{$2^{\text {nd }}$} & M & P/hətnə९əh 'you' & tinəSəh 'you two' & tənnæYəh 'you' \\
\hline & $\mathrm{F}$ & P/hitnæSəh 'you' & tinəSəh 'you two' & tennæYəh 'you' \\
\hline \multirow[t]{2}{*}{$3^{\mathrm{rs}}$} & M & jhenəIəh 'he' & jehınəSəh 'they two' & jhennəSəh 'they' \\
\hline & $\mathrm{F}$ & sE:nə९əh 'she' & jehinəSəh 'they two' & sennəIəh 'they' \\
\hline
\end{tabular}

\subsection{Dependent (Suffixed) Personal Pronouns}

All the three Soqotri dialects have the same dependent personal pronouns. These bound morpheme pronouns are suffixed to main verbs, accusative particles such as $t$ - and $q$ which follow the verb, prepositions or in a few cases to nouns. The full paradigm of these suffix personal pronouns in Soqotri is given in the following table:

Table 7. Dependent Suffix Personal Pronouns in the Three Soqotri Dialects

\begin{tabular}{|c|c|c|c|c|}
\hline Person & Gender & Singular & Dual & Plural \\
\hline $1^{\mathrm{st}}$ & $\mathrm{M} / \mathrm{F}$ & -i / -he / to 'me' & -ki 'us two' & -ən,-tpn 'us' \\
\hline $2^{\text {nd }}$ & $\begin{array}{l}M \\
F\end{array}$ & $\begin{array}{l}-\mathrm{k} \text { ‘you' } \\
-\int \text { 'you' }\end{array}$ & $\begin{array}{l}\text {-ki 'you two' } \\
\text {-ki 'you two' }\end{array}$ & $\begin{array}{l}\text {-kən 'you' } \\
\text {-kən 'you' }\end{array}$ \\
\hline $3^{\text {rd }}$ & $\begin{array}{l}\mathrm{M} \\
\mathrm{F}\end{array}$ & $\begin{array}{l}-\mathrm{j} \varepsilon \mathrm{h},-\int,-\mathrm{t} \varepsilon \mathrm{j} \dot{\mathrm{g}} \text { 'him' } \\
-(\mathrm{t} \varepsilon) \mathrm{s},-(\mathrm{t} \varepsilon) \int \text { 'her' }\end{array}$ & $\begin{array}{l}\text {-hi 'them two' } \\
\text {-hi 'them two' }\end{array}$ & $\begin{array}{l}\text {-jhən, - - } ә \text { ' 'them' } \\
\text {-sən, -tsən'them' }\end{array}$ \\
\hline
\end{tabular}

When these pronouns are added to verbs, accusative particles (t-, $\left.\mathrm{S}_{-}\right)$and prepositions they function as objects:
(10) $\mathrm{Ba}: j \varepsilon h$
Si: nə
$-\mathrm{S}$
kəlb
woman
see3SG.M.PER
-her3SG.F.SUF.PRO
dog SG.M
'The dog saw the woman.'
I see-1SG.M.PER
'I saw him.'

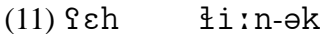
t- $\varepsilon h$
ACC.PAR-3SG.M.SUF.PRO
(12) 1 i : nə
§-ən 
The Pronominal System of the Soqotri Dialects: A structural and functional Study

see.13SG.M.PAS ACC.PAR-.I.PL.M.SUF.PRO.us

'He saw us.'

(13) mon men -hən

which of -1PL.SUF.PRO. us

'Which of us?'

Sometimes these dependent personal pronouns are suffixed to nouns that indicate kinship relation such as father, mother, uncle, etc. In such case the dependent pronouns perform a possessive function.

(14) $\chi \varepsilon: 1-\mathrm{k}$

Maternal uncle-2SG.M.SUF.PRO

'Your maternal uncle.'

Naumkin (1998) states that the third person plural feminine suffix pronoun is (-hin ) but the data collected by the researcher confirm that this suffix pronoun is (-sen) not (-hin). (-hin) is used in Arabic not in Soqotri.

The table above shows that there is more than one suffix personal pronoun used for third person singular masculine pronoun. The use of these suffix pronouns is governed by the subject of the sentence. If the subject of the sentence is a first or second person pronoun, the suffix (-tعijeh) is used as an object. If the subject of the sentence is the third person masculine pronoun. The suffix object pronouns $\left(-\mathrm{j} \varepsilon \mathrm{h}\right.$ or $\left.-\int\right)$ are used as objects and when the subject of the sentence is a third person feminine pronoun, it will have the suffix pronoun $-\int$ as its object.
(15) la:tәь-k -tєijeh
Kill-1SG.PAST -3SG.M.him
'I killed him.'
(16) la:tәь - $-\int$
kill3SG.PAST -3SG.M.him

'She killed him.'

The third person singular feminine pronoun has also two suffix object pronouns -tes and $-t \varepsilon \int$. Their use is also governed by the subject of the sentence. When the sentence subject is a first person pronoun, a second person pronoun or a third person feminine pronoun, the suffix object pronoun -tes is used.

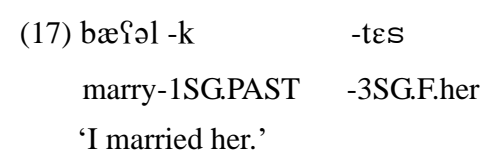

\section{Possessive Pronouns}

There are two types of possessive pronouns in all the three Soqotri dialects. The first 
type includes pronouns that can be described as independent since they can occur either alone functioning as subjects and complements or before possessed nouns. These pronouns are formed linearly by adding the possessive particle $d \varepsilon$ to the independent personal pronouns [d $\varepsilon+$ Independent Pro.] as shown in the following table:

Table 8. Independent Possessive Pronouns in the Three Soqotri Dialects

\begin{tabular}{|c|c|c|c|c|}
\hline Person & Gender & Singular & Dual & Plural \\
\hline $1^{\mathrm{st}}$ & $\mathrm{M} / \mathrm{F}$ & deho 'my, mine' & deki 'ours the two' & dћعn 'ours' \\
\hline $2^{\text {nd }}$ & $\begin{array}{l}\mathrm{M} \\
\mathrm{F}\end{array}$ & $\begin{array}{l}\text { dət 'your, yours' } \\
\text { dit 'your, yours' }\end{array}$ & $\begin{array}{l}\text { deti 'yours the two' } \\
\text { deti 'yours the two' }\end{array}$ & $\begin{array}{l}\text { deton,tin 'yours the two' } \\
\text { deten,tin 'yours the two' }\end{array}$ \\
\hline $3^{\text {rd }}$ & $\begin{array}{l}M \\
F\end{array}$ & $\begin{array}{l}\text { deh, dhi 'his' } \\
\text { desch,dsch, detseh } \\
\text { 'her, hers' }\end{array}$ & $\begin{array}{l}\text { dehi, dhi 'theirs' } \\
\text { dehi, dhi 'theirs' }\end{array}$ & $\begin{array}{l}\text { dehin ,dhn 'theirs' } \\
\text { desen, dsen 'theirs' }\end{array}$ \\
\hline
\end{tabular}

In the following examples, the independent possessive pronouns function as a subject and as a complement respectively:
(18) $\mathrm{d} \varepsilon \mathrm{ho}$
ISG.POSS.PRO
'Mine is good.'
$\varnothing$
$\int k \varepsilon: \mathrm{r}$
COP good. SG.M
(19) $\mathrm{d} \varepsilon \int$
k'a: $9 \varepsilon \mathrm{r} \quad$ dhəh
$\varnothing \quad$ deho
DEM.SG.F
house SG.F
here $\quad \mathrm{COP}$
ISG.POSS.PRO
'This house is mine.'

They can also occur before the possessed nouns.
(20) deho k'ak'ə
Jə d əh
My brother
comel3SG.M.PER
'My brother came.'

The second type of possessive pronouns includes pronouns that may be described as dependent because they never occur alone. They always precede the possessed nouns. These pronouns are formed also linearly through adding the prefix $\mathrm{m}$ - to the dependent suffixed personal pronouns [ $\mathrm{m}+$ Dependent Pro.].

Table 9. Dependent Possessive Pronouns in the Three Soqotri Dialects

\begin{tabular}{|c|c|c|c|c|}
\hline Person & Gender & Singular & Dual & Plural \\
\hline $1^{\mathrm{st}}$ & $\mathrm{M} / \mathrm{F}$ & mənh $\varepsilon$ & məni & mən \\
\hline $2^{\text {nd }}$ & $\begin{array}{l}M \\
F\end{array}$ & $\begin{array}{l}\text { mək } \\
\text { məS }\end{array}$ & $\begin{array}{l}\text { məki } \\
\text { məki }\end{array}$ & $\begin{array}{l}\text { mikən } \\
\text { miken }\end{array}$ \\
\hline $3^{\text {rd }}$ & $\begin{array}{l}\mathrm{M} \\
\mathrm{F}\end{array}$ & $\begin{array}{l}\text { meh } \\
\text { məs }\end{array}$ & $\begin{array}{l}\text { mihi } \\
\text { mihi }\end{array}$ & $\begin{array}{l}\text { mihən } \\
\text { məsen }\end{array}$ \\
\hline
\end{tabular}

(21) mos mokfəm josor 
The Pronominal System of the Soqotri Dialects: A structural and functional Study

her child ill-SG.M

'Her child is ill.'

\section{Reflexive Pronouns}

The Soqotri dialects have no distinct reflexive pronouns. They employs, instead, the preposition [b] which means 'with' and the word nhof 'self' plus the suffix personal pronoun $[b+n h o f+$ Suffix Pro.]. This finding is totally consistent with Lipinski (2001) and Rubin (2004) who point out the proto-Semitic language had no distinctive reflexive pronouns so the Semitic languages developed their own ways for expressing reflexivity through the use of the noun nhof meaning 'self'. The following table contains the full paradigm of these Soqotri reflexives.

Table10. Reflexive Pronouns in the Three Soqotri Dialects

\begin{tabular}{|c|l|l|l|l||}
\hline \hline Person & Gender & \multicolumn{1}{|c|}{ Singular } & \multicolumn{1}{c|}{ Dual } & \multicolumn{1}{c|}{ Plural } \\
\hline $1^{\text {st }}$ & M/F & nhofi 'myself' & nhofki 'ourselves (two)' & nhofən 'ourselves' \\
\hline $2^{\text {nd }}$ & $\begin{array}{l}\text { M } \\
\text { F }\end{array}$ & $\begin{array}{l}\text { nhofk 'yourself' } \\
\text { nhofS 'yourself' }\end{array}$ & $\begin{array}{l}\text { nhofki 'ourselves (two)' } \\
\text { nhofki 'ourselves (two)' }\end{array}$ & $\begin{array}{l}\text { nhofkən'yourselves' } \\
\text { nhofken 'yourselves' }\end{array}$ \\
\hline $3^{\text {rd }}$ & $\begin{array}{l}\text { M } \\
\text { F }\end{array}$ & $\begin{array}{l}\text { nhof ' 'himself' } \\
\text { nhofs 'herself' }\end{array}$ & $\begin{array}{l}\text { nfoj 'themselves(two)' } \\
\text { nfoj 'themselves(two) }\end{array}$ & $\begin{array}{l}\text { nhofən'themselves' } \\
\text { nhosen 'themselves' }\end{array}$ \\
\hline
\end{tabular}

These pronouns are used as objects when the subject and the object of an action are the same as illustrated in this example:
(22) jeh
?ยnћə
$[\mathrm{b}-$
nhof-əS ]
he burn 3SG.M.PER
with REF.PRO-3SG.M
'He burnt himself.'

Reflexive pronouns in the Soqotri dialects are not restricted to objective use; they are also used as intensifiers for subjects or any other pronominal forms as in these examples:
(23) $\mathrm{s} \varepsilon \mathrm{h}$
I
b- nhof-i
玉i : n-ək
ich
PREP-.REF.PRO-1SG.
see-1SG.PER him
'I, myself, saw him.'
(24) $f a: ' t m \varepsilon h$
b- nhof-s
J ədoћ-ph
Fatemah
PREP-.REF.PRO - 3SG.F
came-3SG.F.PER

'Fatemah herself came.'

\section{Reciprocal Pronouns}

Reciprocal pronouns in Soqotri are similar to the reflexive ones both functionally and semantically. They are formed by adding the dual and plural suffix personal pronouns of the first, second and third persons to the word $t \varepsilon$ : tət" "each other' [ $t \varepsilon: t ə t+D u a l / p l u r a l$ 
suffix Pro.]. The following table contains the full paradigm of these pronouns:

Table 11. Reciprocal Pronouns in the Three Soqotri Dialects

\begin{tabular}{|c|c|c|c|}
\hline Person & Gender & Number & Reciprocal Pronouns \\
\hline \multirow[t]{2}{*}{$1^{\mathrm{st}}$} & $\mathrm{M} / \mathrm{F}$ & dual & te:tət'ki \\
\hline & $\mathrm{M} / \mathrm{F}$ & plural & tย: tət’ən \\
\hline \multirow[t]{2}{*}{$2^{\text {nd }}$} & $\mathrm{M} / \mathrm{F}$ & dual & tع:tət’ki \\
\hline & $\mathrm{M} / \mathrm{F}$ & plural & tع:tət'kən \\
\hline \multirow[t]{4}{*}{$3^{\text {rd }}$} & M & dual & te:tət'hi \\
\hline & $\mathrm{F}$ & dual & te: tət'si \\
\hline & M & plural & te: tət'hən \\
\hline & $\mathrm{F}$ & plural & te: tət'sen \\
\hline
\end{tabular}

The following examples illustrate the use of the reciprocal pronouns in Soqotri.
(25) kih
Sini-ki
[ te: tət'-ki]
we. 1DU
see -1DU.PER
REC.PRO-1DU
'We (the two) saw each other.'

$$
\begin{array}{lll}
\text { (26) } j i: h & \text { Si:n-oh } & \text { [tetət'-hi] } \\
\text { 3.DU.M } & \text { see-.3DU.M.PER } & \text { REC.PRO-3.DU.M }
\end{array}
$$

'They (the two) saw each other.'

In the above examples, the two participants (each of whom is both agent and target in different instances of punching) are coordinated as subject, and the predicate is followed by (each other) (Dixon, 2005).

\begin{tabular}{|c|c|c|}
\hline Number & Masculine & Feminine \\
\hline Singular & d $\varepsilon . . . d \hbar ə h$ 'this' & $\mathrm{d} \varepsilon \int . . . \mathrm{dh} \partial \mathrm{h}$ 'this' \\
\hline Dual & deki...dhəh 'these' & $\mathrm{d} \varepsilon \int \mathrm{i} . . . \mathrm{d}$ həh 'these two' \\
\hline Plural & lE...lћəh 'these' & lع...lћəh 'these' \\
\hline
\end{tabular}

\section{Demonstrative Pronouns}

Demonstratives in Soqotri are used with nouns or instead of them to show either distance from or proximity to the speaker. Soqotri has eight demonstrative pronouns: 'this M / F', 'these $\mathrm{M} / \mathrm{F}$ ', 'that M / F', 'those $\mathrm{M} / \mathrm{F}$ '.

Table 12. Demonstratives of Proximity in the Three Soqotri Dialects

Demonstratives of proximity and demonstratives of distance in the Soqotri dialects consist of two parts: the first part is the demonstrative pronoun $d \varepsilon$, deki, d $\varepsilon \int, d \varepsilon \int i$ or $l \varepsilon$ and the second part is the adverb of place dhəh 'here', dbo k' 'there', lhəh 'here', or lbok' 'there'. This type of demonstrative is similar to the double demonstrative. That occurs in some languages such as French (Dryer, 2007a). 
The Pronominal System of the Soqotri Dialects: A structural and functional Study

Table 13. Demonstratives of Distance in the Three Soqotri Dialects

\begin{tabular}{|c|c|c|}
\hline Number & Masculine & Feminine \\
\hline Singular & $\mathrm{d} \varepsilon \ldots \mathrm{dbo} \mathrm{k}$ 'that' & d $\varepsilon \int \ldots d b p k$ '..that' \\
\hline Dual & deki... dbok' ' those' & $\mathrm{d} \varepsilon \int \mathrm{i} \ldots \mathrm{dbok}$ ' 'those the two' \\
\hline Plural & lع...lbok 'those' & $1 \varepsilon \ldots 1$ bok 'those' \\
\hline
\end{tabular}

The demonstrative pronoun forms a syntactic unit with a noun to convey the concept of particular proximity or distance, thus functioning as a determiner of nouns. In this use the two parts of the demonstratives occur:
(27) $\mathrm{d} \varepsilon \int \quad$ ba:jeh dhəh $\varnothing \quad$ Jke:r-eh
DEM.SG.F-this woman-SG.F here-SG COP beautiful-SG.F
'This woman is beautiful.'
(28) deki $\quad$ Ba: $\mathrm{J}^{-\mathrm{i}} \mathrm{dbok}$
DEM.DU.M man-DU.M there
'Those two men...'

The demonstrative can stand by itself, thus functioning as a noun substitute. In this case the second part of the demonstrative can be dropped:
(29) $\mathrm{i} \mathrm{:} \mathrm{k}$
$\mathrm{d} \varepsilon \int$
1SG.IMP-want
DEM.SG.F-this
'I want this.'

The demonstrative pronoun is also used as a definite article. Soqotri, as Johnstone (1970) states, has no distinct indefinite and indefinite articles. However, Johnstone (ibid) does not refer to the means used now to perform the functions of definiteness and indefiniteness in this language. Soqotri is not the only Semitic language that has no articles. According to Rubin (2004) the Proto-West Semitic Akkadian and Classical Ethiopic also have no definite articles. However, Rijkhoff (2002) and Dryer (2005a, 2005b, 2007) point out that some languages which do not have special (in) definiteness markers resort to the distal demonstrative pronouns and the numeral (one) to express the notions of definiteness and indefiniteness respectively. This is true for Soqotri in which the demonstratives $d \varepsilon \int$ 'this' $\mathrm{F}, \mathrm{d} \varepsilon$ 'this' $\mathrm{M}$ or $1 \varepsilon$ 'these' $\mathrm{M} / \mathrm{F}$ are used as definite articles.

$$
\begin{array}{cclll}
\text { (30) to: } \jmath \varepsilon r-k & \text { } ว: z & d \varepsilon-\int & \text { } ว: z & \int k \varepsilon: r-\varepsilon h \\
\text { buy - 1SG.M.PER } & \text { goat } & \text { this DEM -.3.SG.F } & \text { goat } & \text { good.SG.F. }
\end{array}
$$

'I bought a goat the goat is good.'

In the above example the noun P०: $\mathrm{z}$ becomes definite as a result of being mentioned for the second time, therefore, it is preceded by the demonstrative pronoun $d \varepsilon-\int$ which functions as a definite article. If the noun is known to the listener it is usually preceded by the demonstrative functioning as a definite article even if it is mentioned for the first time. 


\section{Khaled Awadh Bin Mukhashin \& Munir Shuib}
(31) $d \varepsilon$
fedhen
९०:k'ยr
DEM.SG.M
mountain.SG.M
big.SG.M
'The mountain is big.'

The word $f \varepsilon d h \varepsilon n$ 'mountain' is definite for both the speaker and the listener and as a result of that it has been preceded by the demonstrative $d \varepsilon$ which performs the function of the definite article 'the'. If the noun is not known neither to the listener nor to the speaker and mentioned for the first time, it will be either used alone without the demonstrative or with the numeral tod 'one' which will mark its indefiniteness.

\section{Relative Pronouns}

The particle $d \varepsilon$ performs many functions in Soqotri. It is used in forming demonstrative pronouns, possessive pronouns and relative pronouns. Relative pronouns in the Soqotri inflect for number and gender as shown in the following table:

Table14. Relative Pronouns in the Three Soqotri Dialects

\begin{tabular}{|l|c|c|}
\hline Number & Masculine & Feminine \\
\hline Singular & $\mathrm{d} \varepsilon$ & $\mathrm{d} \varepsilon \int$ \\
\hline Dual & $\mathrm{d} \varepsilon \mathrm{ki}$ & $\mathrm{d} \varepsilon \int \mathrm{i}$ \\
\hline Plural & $\mathrm{l} \varepsilon$ & $1 \varepsilon$ \\
\hline
\end{tabular}

The function of the relative pronoun is to relate an element in the subordinate relative clause to either a noun or a noun phrase in the main clause of the sentence.
(32) вәу
$\mathrm{d} \varepsilon$
jə-ha:rek'
hi: bas
man REL.SG.M-who
3SG.M.IMP-steal
jail \3SG.M.PER PASS.
'The man who steals was jailed.'

Simeone-Senelle (1997) indicates that the particle $d \varepsilon$ is used as a relative pronoun in Soqotri but she (ibid) does not refer to the fact that this pronoun agrees in number and gender with the noun it modifies as shown in the above table.

Keenan (1985:149) states that relative pronouns "are typically the same as, or morphologically related to, the demonstrative pronouns." This statement is consistent with the findings of the current study which show that the relative pronouns and the demonstrative pronouns in the Soqotri are morphologically the same.

\section{Interrogative Pronouns}

Soqotri has many interrogative pronouns used for asking about the subject, the transitive verb object, the extended transitive verb object and possession. The interrogative pronouns used to ask about the subject are (mən 'who', $? ә j$ 'which', fol 'what')
(33) mən
$j-\int \varepsilon m t \varepsilon l$
sək'ət'rijəh ? 
The Pronominal System of the Soqotri Dialects: A structural and functional Study

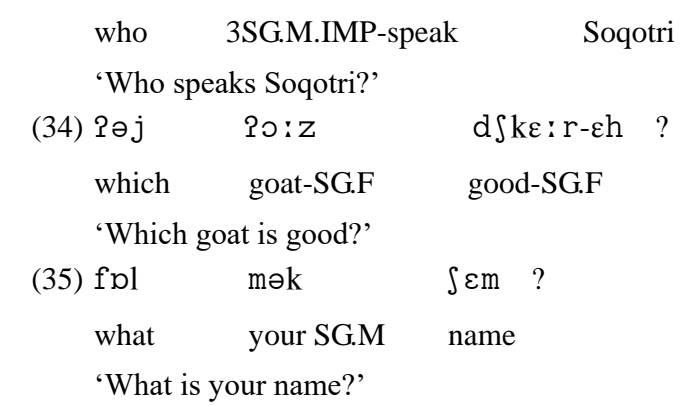

The interrogative pronouns used to ask about transitive verb objects are (mən 'whom', ? $\varepsilon$ nem 'what'). The interrogative word mən is used to ask about the subject and about the object. So mən can not by itself indicate which part of the proposition the speaker wants to know about. That means it cannot determine whether it is subject or the object, the addressee is asked to provide information about. However when it is followed by an intransitive verb it asks about a subject and when it is followed by a transitive verb and an object it also asks about a subject, but when it is followed by a transitive verb without mentioning the object, it asks about an object as illustrated in these examples:

$$
\begin{aligned}
& \text { (36) mən ¥i:n-ək ? } \\
& \text { whom 2SG.M.PER-see } \\
& \text { 'Whom did you (M) see?' } \\
& \text { (37) mən ksa:-S ? } \\
& \text { who find- 2SG.F.PER } \\
& \text { 'Whom did you (F) find?' }
\end{aligned}
$$

Even when mən is used to ask about the object, it can be also followed by a relative clause:

$$
\begin{aligned}
& \text { (38) } m ə n \text { RCL[ d- } 9 i: k \text { ] } \\
& \text { which REL.SG.M 2SG.M.IMP- want } \\
& \text { 'Whom do you want?' }
\end{aligned}
$$

Though most of the interrogative words in the Soqotri usually occur at the beginning of the interrogative sentence, mən can occur at the end of the interrogative sentence when it is used to ask about the object:
(39) k' $\varepsilon$ : bt-ək mən ?
2SG.M.PER-teach who
'Whom did you teach?'

The interrogative pronoun ?enem 'what' can also be used to ask about the object as in this example:
(40) Penem tə-§a:mer ?

$$
\text { what 2SG.MIMP- say }
$$




\section{Khaled Awadh Bin Mukhashin \& Munir Shuib}

'What are you saying?'

fol can also be used as an interrogative adverb meaning 'how' to ask about the manner or way an action or event happened.
(41) fol tək'o:dir teh ?
how 2SG.FIMP- cook meat

'How do you (F) cook meat?'

The interrogative pronoun demhon 'whose' is used to ask for possession.
(42) demhon be:beh s'a:mə ?
whose father die 13 SG.M.PER
'Whose father died?'

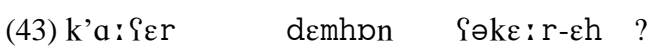
house SG.F whose big SG.F
'Whose house is big?'

\section{Conclusion}

The Soqotri dialects have a very rich pronominal system. It has personal pronouns, possessive pronouns, reflexive pronouns, reciprocal pronouns, demonstrative pronouns, relative pronouns and interrogative pronouns. Soqotri pronouns inflect for person (first person, second person, third person), number (singular, dual plural), and gender (masculine and feminine). The three Soqotri dialects (Eastern Soqotri Dialect, Middle Soqotri Dialect and Western Soqotri Dialect) have almost the same pronouns. Variation almost does not exist except in the case of the suffixes that are added to the independent subject personal pronouns.

The Soqotri dialects have personal pronouns with full forms (with suffixes) and shortened forms (without suffixes), the former pronouns are used in formal situations and folk literature, while the shortened forms are used in every day language. Pronouns in these dialects performs many functions. They are used as subjects, objects, predicates, copulas, and articles.

\section{References}

Dixon, R. M.W. 2005. A semantic approach to English grammar [M]. $2^{\text {nd }}$ ed. New York: Oxford University Press.

Dryer, M. S. 2005a. Definite article [A]. In: M. Haspelmath, M.S. Dryer, D. Gil, \& B. Comrie, eds. The world atlas of language structures [C]. Oxford: Oxford University Press.154-155.

——. 2005b. Indefinite article [A]. In: M. Haspelmath, M. S. Dryer, D. Gil, \& B. Comrie, eds. The world atlas of language structures [C]. Oxford: Oxford University Press.158-159.

——. 2007. Noun phrase Structure [A] In: T. Shopen, ed. language typology and syntactic description: complex construction [C],Vol.2..2 ${ }^{\text {nd }}$ ed.Cambridge: Cambridge University Press. 244-275.

Johnstone, T. M. 1970. A definite article in the modern South Arabian languages [J]. Bulletin of the School 
The Pronominal System of the Soqotri Dialects: A structural and functional Study

of Oriental and African studies, 33(1):259 -307.

Keenan, E. L. 1985. Relative clauses [A]. In:T. Shopen, ed. Language typology and syntactic description: Complex Constructions [C].Vol.2. Cambridge: Cambridge University Press.141-170.

Liebhaber, S. J. 2007. Bedouins without Arabic language, Poetry, and the Mahrah of South-east Yemen [D]. Ph.D. Berkeley: University of California.

Leslau, W. 1938. Lexique Soqotri avec Comparaisons et Explications Etymologiques [M]. Paris: Librairie C. Klincksieck.

Naumkin, V. V. 1998. Personal pronouns in Socotran folklore texts [A]. In the proceedings of the seminar for Arabian studies [C]. 28:229-232.

Rijkhoff, J. 2002. The noun phrase [M]. Oxford: Oxford University Press.

Rubin, A. D. 2004. Studies in Semitic Grammmaticalization [D]. PhD. Harvard University.

Simeone-Senelle, M. C., 1997. The Modern South Arabian languages [A]. In :R. Hetzron, ed. The Semitic languages [C]. London: Routledge. 378-423.

Zorman, T. 2006. Soqotra [OL]. Available at: http://www.yemeni-dream.com [accessed 3 January 2007]. 